\title{
A Supramolecular Approach to Protein Labeling. A Novel Fluorescent Bioassay for Concanavalin A Activity
}

\author{
Oleksandr Rusin ${ }^{\dagger}$, Vladimír Králł, Jorge O. Escobedo ${ }^{\dagger}$, and Robert M. Strongin ${ }^{\dagger}$ \\ Vladimír Král: kralv@vscht.cz \\ tDepartment of Chemistry, Louisiana State University, Baton Rouge, Louisiana 70803 \\ ‡Institute of Chemical Technology, Department of Analytical Chemistry, Technická 5, 16628 , \\ Prague, Czech Republic
}

\section{Abstract

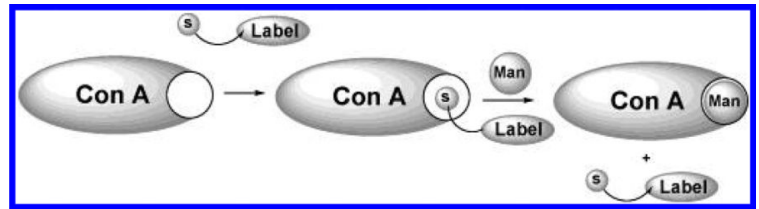

A new method for the bioassay of concanavalin A is based on the interaction of saccharidesubstituted oligopyrrolic macrocycles with lectins. A general sensing mechanism involves the interaction of aggregated and primarily nonfluorescent labels with the target protein, label deaggregation, site-specific binding, and fluorescence signaling. Addition of saccharides to the fluorescent lectin-macrocycle complex leads to the release of the label and partial quenching of fluorescence due to reaggregation. Specificity of the protein-probe binding is discussed.

The development of fluorescent assays for saccharides is a major area in bioanalytical chemistry. Techniques for monitoring the noncovalent binding of saccharides to specific proteins often require complex instrumentation, such as isothermal calorimetry, NMR, or immunochemical assays. ${ }^{1-6}$ Synthetic saccharide receptors are also used. ${ }^{7-26}$

The concept of visualizing saccharide binding via labeled lectins has been discussed in several papers. ${ }^{27-31}$ Current techniques for the fluorescent labeling of proteins employ a number of synthetic dyes and related compounds. ${ }^{32-42,43}$ The interactions of carbohydrates with lectins have also been monitored by Eu-containing macrocycles. ${ }^{44,45}$ Lectinpyranoside interactions have been studied using 4-methylumbelliferyl pyranosides, a dyemodified dextran, or covalent post-photoaffinity labeling. ${ }^{27,46,47}$

These elegant techniques allow the introduction of fluorescent labels proximal to the binding site of Con A and the direct monitoring of saccharide binding by fluorescence spectroscopy.

One of the advantages of covalently labeling proteins is the effective identification of target molecules and the facile monitoring of their properties. However, covalent fluorescent labeling may result in diminished sensitivity and/or changes in selectivity if the label is relatively far from the active site. It may also produce allosteric changes in the active site.

(C) 2004 American Chemical Society

Correspondence to: Vladimír Král, kralv@vscht.cz.

Supporting Information Available: MALDI MS of the complex 1-ConA and experimental details. This material is available free of charge via the Internet at http://pubs.acs.org. 
For instance, this latter effect has been observed after the covalent modification of Con A, leading to a 4 - to 5-fold reduction in the association constant toward glycopyranosides. ${ }^{27}$

Noncovalent fluorescent labeling procedures typically require a direct interaction of a fluorescent label with the binding site of a target protein. Substrate detection can then be monitored indirectly as the substrate displaces the label from the binding site. We describe herein a facile method for the indirect monitoring of lectin-saccharide interactions via site specific noncovalent fluorescent labeling. Our strategy is based on the formation of weakly fluorescent noncovalent complexes of Con A with various "pseudo-substrates" (saccharideappended oligopyrrolic macrocycles, Figure 1). It is well-known that these macrocycles are highly aggregated in aqueous media which results in diminished fluorescence. When Con A is added to solutions of the macrocycles, deaggregation may occur upon formation of a noncovalent complex with the lectin. These processes are accompanied by a strong increase in fluorescence. Subsequent addition of a natural substrate (e.g., o-mannose), which has a higher affinity for Con A, leads to the release of the weakly bounded pseudosubstrate with concomitant re-aggregation and quenching of fluorescence (Scheme 1). No spectral changes are observed upon addition of mannose, glucose, fructose or galactose to aqueous solutions containing only macrocycles 1-10.

Figure 2 exibits the process of deaggregation of probe $\mathbf{1}$ and the formation of its complex with Con A as evidenced by UV-vis spectroscopy. The addition of Con A to an aqueous solution of 1 leads to a decrease of the Soret band at $400 \mathrm{~nm}$ along with the emergence and gradual increase of another maximum at $450 \mathrm{~nm}$. The appearance of the new maximum at $450 \mathrm{~nm}$, in addition to mass spectrometric evidence (Supporting Information), confirms complexation between the label and protein.

The interactions of the Con A-1 complex with a natural substrate, D-mannose, are monitored by fluorescence spectroscopy (Figure 3). Sapphyrin glucamide 1 exhibits only weak fluorescence with an emission maximum at $690 \mathrm{~nm}$ due to its extensive aggregation in $\mathrm{H}_{2} \mathrm{O}$ (Figure 3, spectrum A). Addition of Con A causes deaggregation and a significant increase in fluorescence (Figure 3, top spectrum B). Subsequent addition of $\mathrm{p}$-mannose results in concentration-dependent fluorescence quenching (Figure 3, B and inset). Qualitatively, macrocycles $\mathbf{2 , 5}$, and $\mathbf{6}$ exhibit similar behavior to $\mathbf{1}$. Each exhibits strongly fluorescent signals when added to solutions of Con A which are quenched upon subsequent displacement of the labels from the binding site by $\mathrm{D}$-mannose.

To determine that the signaling mechanism arises from the specific occupation of $\mathbf{1}$ in the active site of Con A, we initially saturate the lectin's (1 equiv) binding site with 100 equiv Dmannose and then add 1 (10 equiv). Subsequent addition (to the solution of the Con Amannose complex containing $\mathbf{1}$ ) of $\mathrm{p}$-mannose (10 equiv) did not produce detectable fluorescence changes. This result strongly suggests that the lectin active sites must be available to bind to $\mathbf{1}$ in order for mannose-induced displacement of $\mathbf{1}$ and concomitant signaling to occur.

Further evidence that $\mathbf{1}$ binds specifically at the active site of ConA derives from experiments in which denatured lectin (heated at $100{ }^{\circ} \mathrm{C}, 10 \mathrm{~min}$ ) is used for mannose detection. Labels $\mathbf{1 , 2}, \mathbf{5}$, and $\mathbf{6}$ interact only weakly with denaturated lectin (as evidenced by relatively minimal fluorescence changes). Importantly, the complexes are insensitive to mannose addition, exhibiting insignificant $(<1 \%)$ spectral changes. Conversely, the complexes of native Con A with labels 1, 2, 5, and $\mathbf{6}$ display intense fluorescence changes upon addition of natural substrate. 
The addition of $\mathbf{1}, \mathbf{2}, \mathbf{5}$, or $\mathbf{6}$ to solutions of control proteins, bovine serum albumin (BSA), and ovalbumin results in deaggregation of the probe and complex formation (enhanced fluorescence). However, upon addition of $\mathrm{D}$-mannose there is no change in fluorescence intensity. From the experiments performed with Con A, BSA, and ovalbumin it can thus be concluded that the macrocycles 1, 2,5, and $\mathbf{6}$ interact with Con A via specific binding involving the lectin active site. Therefore, macrocycles $\mathbf{1 , 2 , 5}$, and $\mathbf{6}$ may be used successfully for the fluorescent labeling of Con A and in related saccharide sensing experiments.

Interestingly, the interaction of Con A with the macrocycles $\mathbf{3 , 4}$, and $\mathbf{7 - 1 0}$ results in the formation of fluorescent complexes. However, we characterize these complexes as nonspecific. Their insensitivity to the addition of $\mathrm{D}$-mannose is observed (i.e., no fluorescence quenching). This behavior is consistent with a different binding mechanism for $\mathbf{3 , 4}$, and 7-10 as compared to probes $\mathbf{1 , 2 , 5}$, and $\mathbf{6}$. Nonspecific interactions of porphyrins with lectins are very well-precedented. ${ }^{48}$

If a 1:1 stoichiometric ratio is assumed (solely for the purpose of relative comparison) for the labeled Con A and saccharide, this complex can be analyzed using a Benesi-Hildebrandt plot. Table 1 summarizes the relative binding affinities of investigated saccharides.

Finally, we observe that the interactions of sapphyrins 1, 2, and porphyrins 5 and $\mathbf{6}$ with Con A at macrocycle concentrations above $10^{-5} \mathrm{~mol} / \mathrm{L}$ lead to precipitation of the lectinmacrocycle complex. Initial incubation of the lectin with $\mathrm{D}$-mannose, however, prevents precipitation. Precipitation with other proteins (e.g., BSA and ovalbumin) is not observed. This effect might find application in a simple and efficient purification of Con A.

In conclusion, we have described a novel approach toward the noncovalent fluorescent labeling of proteins. Feasibility has been demonstrated using Con A and a series of saccharide-modified macrocycles. Specific interactions of the macrocycles with the lectin indicate the dependence of fluorescence emission on the chemical nature of saccharide substituents, the protein species and the presence of the native tertiary structure of the lectin. The extensive investigation of the binding mechanism is ongoing in our laboratories. The reported technique allows for the ready monitoring of substrate binding. We believe that this method could be of general utility for fluorescence and colorimetric binding studies of various proteins. It may serves as a suitable tool for the simple, nondestructive sensing of many biologically important substrates and for the screening of novel inhibitor libraries of a given protein.

\section{Supplementary Material}

Refer to Web version on PubMed Central for supplementary material.

\section{Acknowledgments}

Financial support from the Ministry of Education of the Czech Republic (CEZ:J19/98:223400008) Alexander von Humboldt Stiftung, the grant agency of the Czech Republic (No. 309/02/1193, 203/02/0933), and an EU grant (No. QLRT-2000-02360) is gratefully acknowledged (V.K.). We also thank the National Institutes of Health for funding via Grant No. R01EB002044 (R.M.S.). We are also grateful to Professor Jonathan L. Sessler of the University of Texas at Austin for supplying porphyrin substrates.

\section{References}

1. Sauernborn MK, Wright LM, Reynolds CD, Grossmann JG, Rizkallah PJ. J. Mol. Biol. 1999; 290:185. [PubMed: 10388566]

2. Lee YC, Lee RT. Acc. Chem. Res. 1995; 28:321. 
3. Creagh AL, Koska J, Johnson PE, Tomme P, Joshi MD, McIntosh LP, Kilburn DG, Haynes CA. Biochemistry. 1998; 37:3529. [PubMed: 9521674]

4. Asensio LJ, Canada FJ, Siebert HC, Laynez J, Poveda A, Nieto PM, Soedjanaamadja UM, Gabius HI, Jimenez-Barbero J. Chem. Biol. 2000; 7:529. [PubMed: 10903932]

5. Asensio LJ, Siebert HC, von der Lieth CW, Laynez J, Bruix M, Soedjanaamadja UM, Beintema JJ, Canada FJ, Gabius HI, Jimenez-Barbero J. Proteins. 2000; 40:218. [PubMed: 10842338]

6. Wu AM, Wu JH, Tsai M-S, Kaltner H, Gabius H-J. Biochem. J. 2001; 358:529. [PubMed: 11535116]

7. James TD, Samankumara S, Shinkai S. Angew. Chem. Int. Ed. Engl. 1994; 33:2207.

8. Davis AP, Wareham RS. Angew. Chem. Int. Ed. 1999; 38:2978.

9. Rusin O, Lang K, Král V. Chem. Eur. J. 2002; 8:655. [PubMed: 11855713]

10. Král V, Rusin O, Schmidtchen FP. Org. Lett. 2001; 3:873. [PubMed: 11263904]

11. Král V, Rusin O, Charvátová J, Anzenbacher P Jr. Tetrahedron Lett. 2000; 41:10147.

12. Charvátová J, Rusin O, Král V. Sens. Actuators, B. 2001:366.

13. Rusin O, Král V. Sens. Actuators, B. 2001:331.

14. Rusin O, Král V. Tetrahedron Lett. 2001; 42:4235.

15. Záruba K, Setnicka V, Charvátová J, Rusin O, Tomanková Z, Hrdlicka J, Král V. Collect. Czech. Chem. Commun. 2001; 66:693.

16. Rusin O, Král V. Mater. Sci. Eng. C. 2001; 18:135.

17. Chmielewski SA. Am. J. Clin. Pathol. 1995; 104:59.

18. Barreau PB, Buttery JI. Med. J. Aust. 1987; 147:286. [PubMed: 3626945]

19. Rosenzweig Z, Kopelman R. Sens. Actuators, B. 1996; 35:475.

20. Walt DR, Lin L. Anal. Chem. 1995; 67:3746. [PubMed: 8644922]

21. Bambot SB, Rao G, Romauld M, Carter GM, Sipior J, Terpetchnig E, Lakowicz JR. Biosens. Bioelectron. 1995; 10:643. [PubMed: 7612212]

22. Kunzelmann U, Bottcher H. Sens. Actuators, B. 1997; 38:222.

23. McDonagh C, MacCraith BD, McEvoy AK. Anal. Chem. 1998; 70:45. [PubMed: 21644598]

24. Lin AL, Feldman MS, Kopelman R. J. Phys. Chem, B. 1997; 101:7881.

25. Rosenzweig Z, Kopelman R. Anal. Chem. 1995; 67:2650. [PubMed: 8849030]

26. Rosenzweig Z, Kopelman R. Anal. Chem. 1996; 68:1408. [PubMed: 8651500]

27. Nagase T, Shinkai S, Hamachi I. Chem. Commun. 2001:229.

28. Satoh A, Matsumoto I. Anal. Biochem. 1999; 275:268. [PubMed: 10552918]

29. Liljeblad M, Ryden I, Ohlson S, Lundblad A, Pahlsson P. Anal. Biochem. 2001; 288:216.

[PubMed: 11152593]

30. Ertl P, Mikkelsen SR. Anal. Chem. 2001; 73:4241. [PubMed: 11569815]

31. Bachhawat K, Thomas CJ, Amutha B, Krishnasastry MV, Khan MI, Surolia A. J. Biol. Chem. 2001; 276:5541. [PubMed: 11076955]

32. Griffin BA, Adams SR, Tsien RY. Science. 1998; 281:269. [PubMed: 9657724]

33. Jin LJ, Giordano BC, Landers JP. Anal. Chem. 2001; 73:4994. [PubMed: 11681478]

34. Colyer CL. Cell Biochem. Biophys. 2000; 33:323. [PubMed: 11325049]

35. Lui R, Sharom FJ. Biochemistry. 1996; 35:11865. [PubMed: 8794769]

36. Parola AL, Lin S, Kobilka BK. Anal. Biochem. 1997; 254:88. [PubMed: 9398350]

37. Ci YX, Yang XD, Chang WB. J. Immun. Methods. 1995; 179:233.

38. Jung K, Jung H, Wu J, Privé GG, Kaback HR. Biochemistry. 1993; 32:12273. [PubMed: 8241112]

39. Biochemistry. 1988; 27:6633. [PubMed: 3219359]

40. Baba A, Nakamura T, Kawakita N. J. Biochem. 1986; 100:1137. [PubMed: 2950079]

41. Bozler H, Jany KD, Pfleiderer G. Biochim. Biophys. Acta. 1983; 749:238. [PubMed: 6419775]

42. Süßmeier F, Langhals H. Eur. J. Org. Chem. 2001; 3:607.

43. Willner I, Rubin S. J. Am. Chem. Soc. 1992; 114:3150.

44. Lee YC, Kawasaki N, Lee RT, Suzuki N. Glycobiology. 1998; 8:849. [PubMed: 9675217]

Org Lett. Author manuscript; available in PMC 2012 June 28. 
45. Oda Y, Nakayama K, Kinoshita M, Kawasaki N, Hayakawa T, Kakehi K, Abdul-Rahman B, Lee YC. Glycobiology. 1999; 9:1132.

46. Gaikward SM, Gurjar MM, Khan MI. Biochem. Mol. Biol. Int. 1998; 46:1. [PubMed: 9784833]

47. Ballerstadt R, Shulz JS. Anal. Chim. Acta. 1997; 345:203.

48. Komath SS, Kenoth R, Giribabu L, Maiya BG, Swamy MJ. J. Photochem. Photobiol. B. 1999; 50:108. 


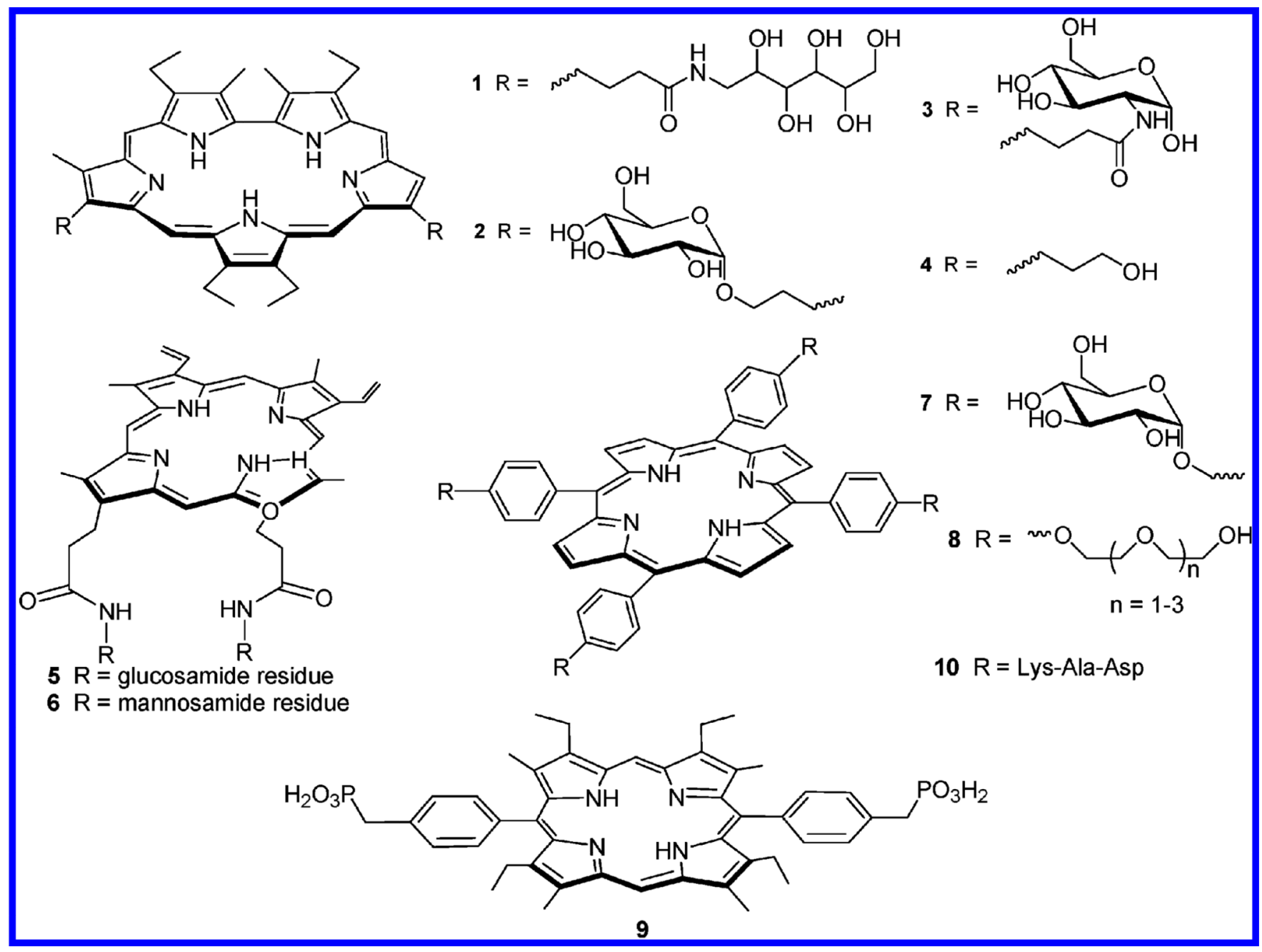

Figure 1.

Sapphyrins 1-4 and porphyrins 5-10. The R groups are chosen to exhibit varying degrees of selectivity to the lectin active site. They also impart water solubility to the lipophilic macrocycles and limit nonspecific hydrophobic interactions with proteins. 


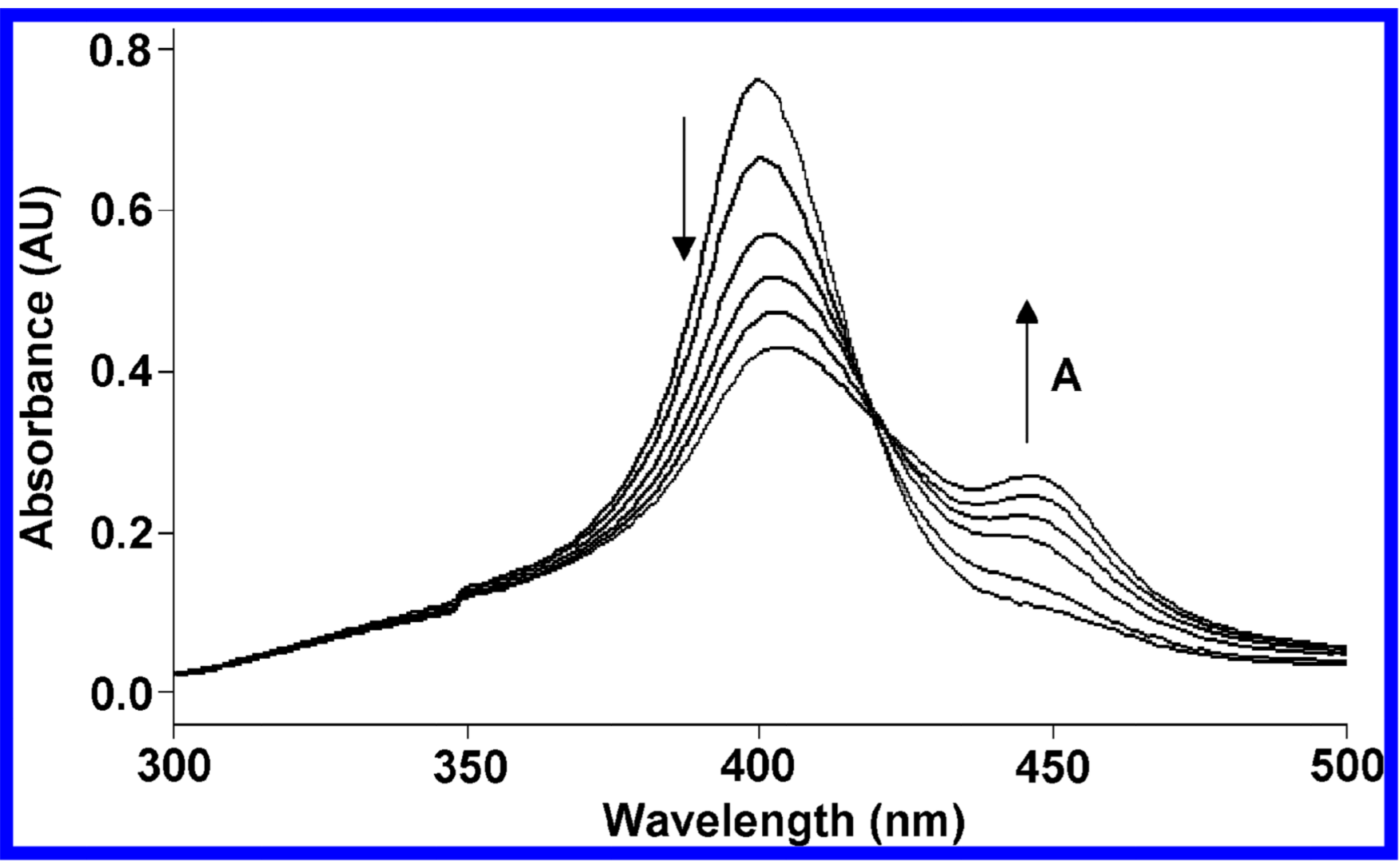

Figure 2.

UV-vis spectra of sapphyrin $\mathbf{1}\left((0-8.5) \times 10^{-5} \mathrm{M}\right)$ added to Con A $(1.0 \mathrm{mg} / \mathrm{mL})$ in $\mathrm{H}_{2} \mathrm{O}$. 


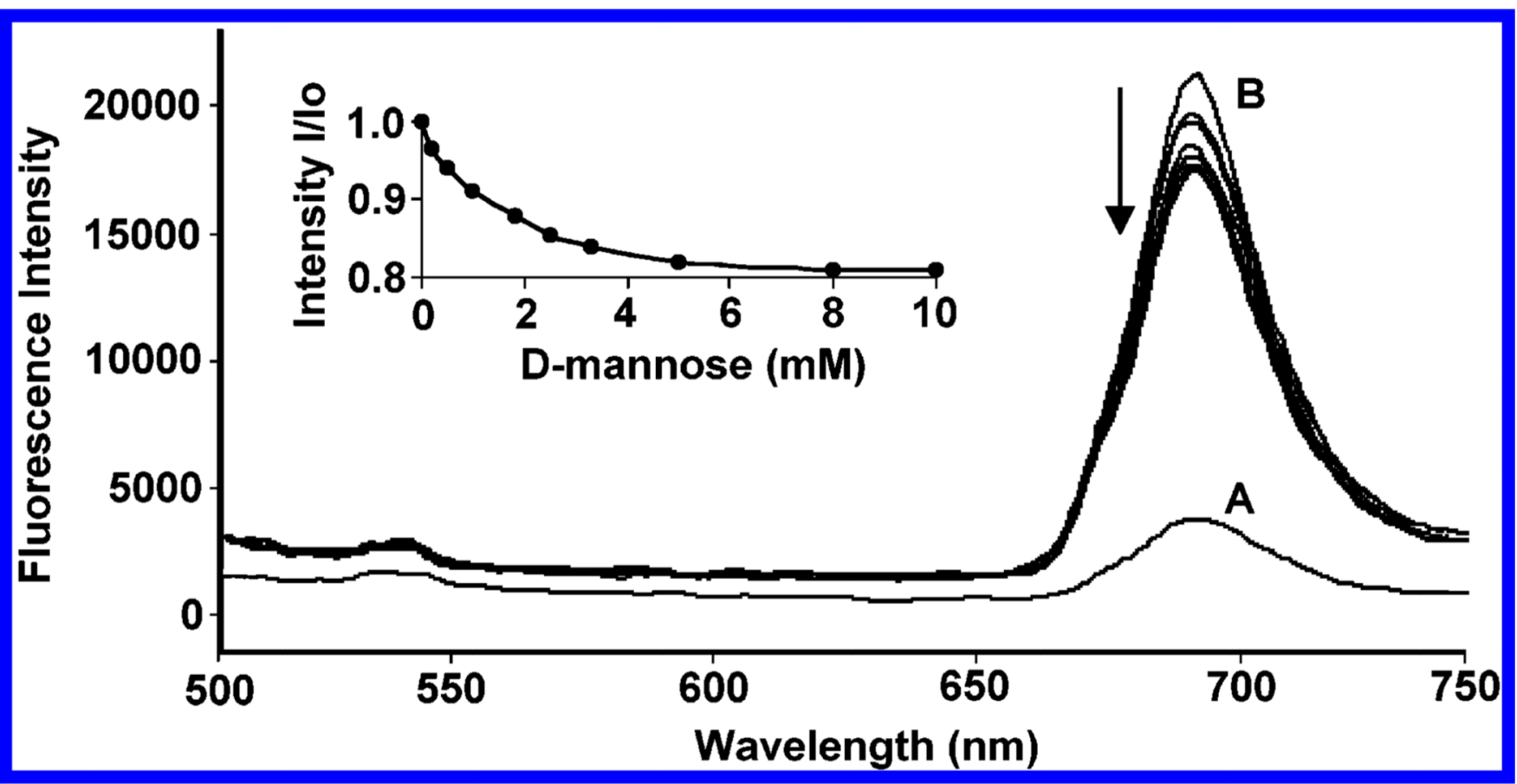

Figure 3.

Fluorescence emission spectra of $\mathbf{1}$, the complex Con A-1, and the complex upon addition of D-mannose. (A) Fluorescence emission of $1\left(8.5 \times 10^{-6} \mathrm{M}\right)$. (B) Fluorescence emission upon addition of Con A (1.0 mg/mL top spectrum). Fluorescence quenching is induced by addition (also indicated in the inset) of $\mathrm{p}$-mannose $\left((0-8.5) \times 10^{-3} \mathrm{M}\right)$. We attribute the fact that complete quenching upon mannose addition does not occur to the presence of deaggregated macrocycles nonspecifically bound to the lectin surface (ref 48). 


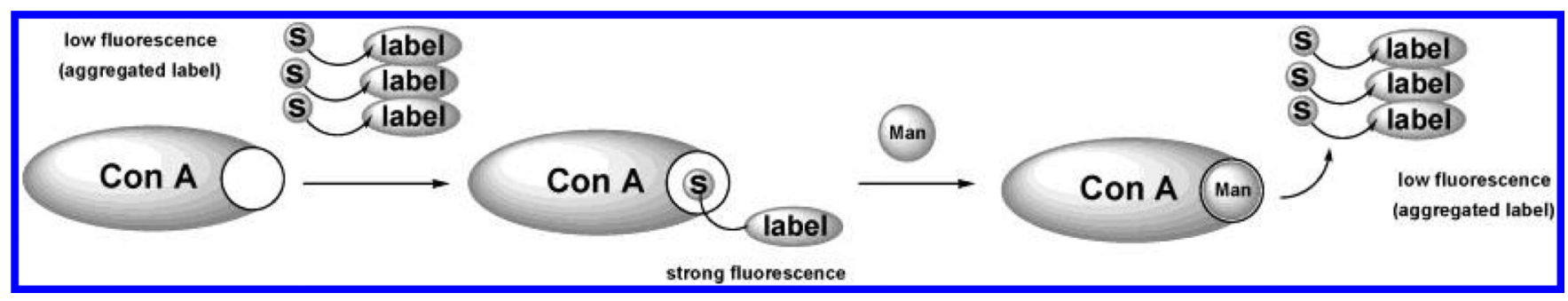

Scheme 1.

Interaction of Con A with a Label Followed by Displacement with a Natural Substrate (s = Saccharide) 


\section{Table 1}

Relative Binding Affinities of Various Saccharides with Fluorescent Macrocycle-Con A Complexes $\left(K \times 10^{4}\right.$ $\left.\left(\mathrm{M}^{-1}\right)\right)$

\begin{tabular}{lcccc}
\hline & \multicolumn{4}{c}{$\begin{array}{c}\text { labels and relative affinities } \\
\text { of saccharides }\end{array}$} \\
\cline { 2 - 5 } saccharide & $\mathbf{1}$ & $\mathbf{2}$ & $\mathbf{5}$ & $\mathbf{6}$ \\
\hline D-mannose & 1.7 & 1.2 & 1.1 & 0.5 \\
D-glucose & 1.1 & 1.0 & 0.6 & 0.3 \\
methyl- $\mathrm{a}$-D-glucopyranoside & 0.6 & 0.9 & 0.2 & 0.01 \\
methyl- $\beta$-D-glucopyranoside & 0.7 & 0.8 & 0.3 & 0.01 \\
\hline
\end{tabular}

